\title{
Islamic Discourse in Ottoman-Safavid Peacetime Diplomacy after 1049/1639
}

\author{
Selim Güngörürler
}

Ottoman-Safavid relations in the period between the late ninth/fifteenth century and early seventeenth centuries are relatively well studied. Because this period was marked by warfare with only brief interruptions, scholars have largely focused on the confrontational, exclusionary, and sectarian discourses. In this context, fatwas on unbelief (kufr), polemical treatises, and based on these, accusations, war declarations, and persecutions have attracted a good deal of scholarly attention.1 For the most part, studies on this subject have approached religion either as a driving factor of the conflict or as one subordinate to politics. This is only natural, because in the successive wars during the one and a half centuries, the Ottoman Empire legitimized its hostility against Safavid Iran by referring to religious dogma and declaring the faith of the Safavids' militant followers, the Kızılbaş, a heresy - the phenomenon which is discussed in this volume from various angles by Nabil Al-Tikriti, Nir Shafir, and Ayşe Baltacıoğlu-Brammer.

However, a study of the bilateral relations between the two monarchies from the peace of Zuhab in 1049/1639 until the overthrow of the Safavid dynasty in 1135/1722 requires a different approach. During this period, political principles, along with the religious terminology that informed them, were reshaped into a new diplomatic discourse. The initiators of this new discourse were exclusively dignitaries and bureaucrats, rather than theologians and jurists. In this role, they ceased to employ religious terminology and legal concepts for the aggravation of hostilities, exploring instead how they could use religious concepts to articulate a unifying, inclusive, and nonsectarian agenda. In order for this to materialize, both parties selected new Islamic themes that were conducive to achieving the newly desired end.

1 See, for instance, Murphey, Süleyman's eastern policy; Diyanet, İlk Osmanlı-İran anlaşması; Dressler, Inventing orthodoxy; Küpeli, Osmanlı-Safevi münasebetleri; Sohrweide, Der Sieg der Safawiden; Kütükoğlu, Osmanlı-Irran münasebetleri. See footnote 36 below for further titles. 
First of all, this required that the ulama's-especially the chief mufti's (şeyhü'l-isläm) - involvement in diplomacy with the Safavids, in which the ulama traditionally played an active role, be discontinued, for the ulama's doctrinal position was too entrenched in sectarian, polarizing discourse to accommodate the state's new reconciliatory approach. ${ }^{2}$ Rather than drawing on the ulama input, the political authority and bureaucracy now took over the role of articulating legal concepts and phrases referencing the Quran and hadith for use in diplomacy in order to make Islamic tradition foster, not delegitimize, the revised goals. In the field of diplomacy, both parties emphasized Islam's inclusivity, took accusations of heresy off the agenda, and adopted a purposeful, almost absolute silence in the matter of Shi'ite-Sunni sectarian discord. They revisited the concept of the caliphate, and through it, articulated in Islamic terms the early modern principle of Ottoman supremacy. In this context, concepts novel to the diplomacy between the Houses of 'Osmān and Șafï, such as "brotherhood-in-religion," prayer exchange, "partnership in heavenly remuneration," and "binding contract before God," gained currency, albeit for a short period of time. Therefore, the use of Islamic discourse as a means to legitimize political goals in Ottoman-Safavid relations continued after 1049/1639; however, it now served policies of convergence rather than confrontation.

\section{Documentary Evidence}

The sultan and his grand vizier on the one hand, and the shah and his chief vizier on the other, exchanged many letters after 1049/1639. Their extant copies are kept in imperial epistle registers (nāme-i hümāyūn defteri) and letter collections (münşe'āt mecmūáası), and, to a certain extent, chronicles (vekayīnāme, tärīh). This diplomatic correspondence illustrates the redefined role of Islamic themes in Ottoman-Safavid relations. The first Ottoman mission (1049-1051/ 1639-1641) sent to Isfahan to ratify the peace of Zuhab is a telling example of how earnestly the Safavids took the Sublime Porte's recognition of their Muslimness. At the behest of Shah Șafì, as the very first official event at court,

2 The chief mufti could also play a role in diplomacy with European states, see White, Fetva diplomacy. For the regulation of international relations by the Islamic canon, see Krüger, Fatwa und Siyar. For the extant fatwas from the period in question, see the survey in Özen, Osmanlı döneminde fetva literatürü. However, in diplomacy with Iranian states, the chief mufti's role was not limited to issuing fatwas but included direct and state-sponsored correspondence with his Iranian counterpart as well. 
the sultan's envoy was taken to the new Grand Mosque of Isfahan to perform the Friday prayer together with the gathered congregation and dignitaries, ${ }^{3}$ indicating the importance attached to leaving the impression of being good Muslims on Ottoman visitors. This is particularly important in light of the early modern controversy among the Shi'ite ulama on whether the Friday prayer was obligatory in the absence of the Imam, and the Sunni ulama's engagement therewith (as discussed in Evren Sünnetçioğlu's paper in this volume).

The next piece of evidence comes from the first extant correspondence following the treaty of Zuhab and showcases the attempt to normalize relations after more than 15 years of warfare. Shah 'Abbās II's letters from 1050/1641 and 1052/1642 acknowledged the Ottomans' exclusive claim to the caliphate and primacy in Islamdom. The royal chancery glorified the sultan as the "exemplification of the beneficence and mercy of the Lord of the worlds," referred to his dignity of being the "servant of the Two Illustrious Sanctuaries," and paid homage to his supreme caliphal position by calling him "God's shadow (zlllullāh)."

In his answer sent in 1053/1643, Sultan İbrāhīm relates his condolences to 'Abbās II for the passing of his father, Shah Șafī, for "whose absolution" ('aleyh el-gufrän) from worldly deeds he prayed-a prayer reserved for those who passed away as Muslims. In the following sentence, the Sublime Porte emphasized the empire's continuous preoccupation with the cause of Islam and the expectation that the Safavids would abstain from any aggression that would hinder Ottoman activities in this respect: "so long as there arises no situation that is contrary to the pact and that will cause our legions to occupy themselves [away] from the obligatory jihad," peace should prevail. Grand Vizier Kemānkeş Mușțafā Pasha's parallel letter to 'Abbās II placed even more emphasis on the concepts above. After wishing the "mercy of God upon Shah Șafi”" ('aleyhi rahmetullāh), and thus acknowledging the House of Șafì to be among the believers, the grand vizier set out to underline the Ottoman monarch's superior position in Islam in the following terms: "God's shadow in both worlds (zullullāh fi-l-älemeyn), helper of Islam and the Muslims, servant of the House of God, confirmed by God." Additionally, by declaring the "jihad against infidels [to be] the seal-ring of the [Ottoman] dynasty," Kemānkeş Mușțafā Pasha stressed the distinction of the Ottomans as the foremost wagers of holy war. ${ }^{5}$

3 Qazvīnī, Khuld-i Barīn 301.

4 Evoğlu, Mecma`283a-b; Cevrī İbrāhīm and Șarı 'Abdullāh, Düstūrü’l-İnşā entry: “Şehinşāh Sulțān İbrāhīm Hān țarafına Şāh 'Abbās-ı Ŝānī cānibinden gelen nāmedir."

5 Cevrī İbrāhīm and Șarı 'Abdullāh, Düstūrü'l-İnşā, the untitled entry following the section 
In the following decade, the relations between Constantinople and Isfahan deteriorated due to the contentions and proxy war over in Basra. In his 1066/1656 epistle sent to disown his past attempts to intervene in Iraq, 'Abbās II hailed İbrāhīm's successor, Mehmed IV, as the "refuge of Islam," 6 while in his follow-up epistle the next year, the shah lauded the sultan's distinction in God's service by calling him the "sharpness of ghaza and jihad, [and the] ornamentor of religion," in addition to remarking that Mecca and Medina belonged to the Ottoman Empire. ${ }^{7}$

Mehmed IV's epistle on the conquest of Crete addressed to the shah in 1080/1669 opened with a thanksgiving to God for "making the caliphal [Ottoman] dynasty distinguish itself among the monarchs of the age by giving [it] accomplishment in the exaltation of the proclamation of God's Oneness ( $i^{\prime} l \bar{a}-$ yı kelime-i tevhìd) and revival of the Prophet's sharia." The ultimate conquest of Crete from the Venetian alliance was declared to have confirmed that the Ottoman dynasty had indeed lived up to God's glad tidings "We made you vicegerent [caliph] on Earth [Q 38:26], God shall help you with a precious victory [Q 48:3], a victory-help from God and imminent conquest [Q 61:13]." Mehmed IV depicted the Cretan war as the continuation of holy war $(g h a z \bar{a})$, which his "caliphal" person, who was the "refuge of religion" (din-penāh), had been "individually obligated" ( far $\dot{z} \iota$ ' ayn) to wage, like each of his forefathers. In obedience to the divine command "and strive duly in the way of God for endeavor [Q 22:78]," said the sultan, he embarked on a holy quest and converted churches into mosques. The glad tidings conveyed in this "caliphal epistle" of Mehmed IV were to make all Muslims rejoice, and upon its arrival, the shah was "to command celebrations, and spread around the glad tidings." ${ }^{8}$

The parallel grand vizierial letter described the "best-possible deeds of monarchs, who are the pillars of the religion and the [Muslim] nation," to be the "exaltation of the word of God [and] jihad." Because of this, stated Köprülüzāde Fāżll Ahmed Pasha, his lord Mehmed IV, as the "aider of Islam and the Muslims (gıyāsü̈l-İslām ve'l-Müslimìn), patron of Islam (ḥāmì-yi Müselmānì), sovereign of the ghäzis and jihad-wagers, the confirmed one before God" had "personally departed for this greater ghazāa, and performed the narrated exploits with

titled "bu cānibden Şāh Abbās-ı Şānī țarafina gönderilmek için sābıḳan reīsülküttāb olan 'Abdullāh Efendi müsvedde ettiği nāmedir, lākin bu mektūb gönderilmeyip ba'dehu yazılan gönderilmiştir."

6 Navāī, Asnād 1038-1105 206.

7 Navāī, Asnād 1038-1105 209.

8 Navāī, Asnād 1038-1105 250. On Mehmed Iv's conversion of churches and synagogues to mosques, see Baer, The great fire of 1660 . 
his army, the "jihad-strivers [in the path] of Islam," on the island of Crete, the "cemetery of jihad." This letter accompanied the above-mentioned imperial epistle in announcing the materialization of God's glad tidings "Muslims will cheer up with the God-helped victory [Q 30:4-5]."9

In 1099/1688, apparently motivated by the shocking losses during the disastrous first half of the Great Turkish War against the Holy League of German states, Poland, Russia, Venice, and the Papacy, the Sublime Porte composed the imperial epistle that would be a game changer in that the Safavids became explicitly included in the community of Islam. First, Sultan Süleymān II defined the Islamic dimension of his reign as such: "[God] the Possessor of the regnum brightens a sunshine of caliphate in every era to reform the subjects; and as it is the tradition of [God] the Almighty to exalt the religion and affirm the sharia, He has crowned Our person with [His revelation] We made you vicegerent [caliph] on Earth [Q 38:26], and enthroned [Us] to the universal caliphate (hilāfet-i cihānbānī). It is necessary that [the news of Our] overwhelming caliphate reach Your Kingly ears."

After this emphasis on the caliphal dignity of his "jihad-associated dynasty," the sultan qualified the empire's ongoing war against the Christian Holy League as the Muslims' endeavor in the way of God and the Prophet. Following this, he called, "with complete union-in-religion" (kemāl-i ittihāad-ı dīn $)$ ), on the shah "to exercise diligence in [upholding] the concord and fervor of the luminous Muslim community" (yek-cihetī ve gayret-keşi-yi millet-i beyżā $).{ }^{10}$

In the imperial epistles of 1080/1669 and 1099/1688, the Ottoman state made its most explicit claim to the caliphate in its relations with the Safavid state since the reestablishment of peace in 1049/1639. Besides, the Ottomans, instead of making references to the Safavids' Muslimness in passing, directly and explicitly addressed it in the 1099/1688 epistle, stating that both parties were of one and the same religion, which necessitated solidarity. This is crucial in the sense that it constituted the first and concrete step taken by the Ottomans toward acknowledging the Islamic legitimacy and thus the permanence of the Safavid rule in Iran.

Shah Süleymān's reply composed in 1102/1691 confirmed this rapprochement by means of addressing the sultan — then Ahmed II —as the possessor of the "greater caliphate (hiläfet-i kübrā), enkindler of the divine light, establisher of the foundation of Islam (mü'essis-i bünyānül-İsläm), servant of the Two Illustrious Sanctuaries, [and] breaker of the heads of the infidels." After

9 Navāī, Asnād 1038-1105 258.

10 Nāme-i hümāyūn v, entry 29. 
paying such a clear homage to Ottoman claims, the shah then declared the "attachment-in-religion" (teveddüd-i din) between the parties and depicted the Ottoman campaigns against the Holy League as an "august march to eradicate the alliance of idol-worshippers." "For the currency of the resplendent sharia," declared the shah, "a prayer from this [Safavid] caliphal family (hānevāde-i hiläfet) of the progeny of the Prophet's dynasty was required." Accordingly, he stated, to have "commanded with heart and soul that in mosques, temples, venues, and habitations, the seyyids, the ulama, the ascetics, and the pious raise the hands to the [Divine] Court in complete servility, [and pray] that the [Ottomans'] army of the Faith (cünüd-ı ehl-i imānn) conquer, and [commanded] that they [i.e., Iranians] set themselves to praying for the celestialvictory of the [Ottoman] troops in the path of God's oneness and appeal for the toppling of the irreligious opponents." This express prayer concluded with the shah's expressing his "honest hope" that the "[Ottoman] jihad-wagers attain their portion from the divine-remuneration (müsevvebāt) of ghazā and jihad."11

Thereby, the Safavids recognized the Ottomans' official position on the caliphate, not for the first time but, more strongly than before. In doing so, they referred to the distinction between the "greater" and the "lesser" versions of this office that had been introduced in the late Middle Ages, according to which the former was caliphate proper as in the monarchy of an Islamic world empire, and the latter was the caliphal authority a monarch enjoyed strictly within his own sovereign territory while paying titular homage to the hierarchically superior "greater caliph."12 The Safavids also acknowledged and advanced the Ottoman position on coreligionism. Instead of rephrasing his commitment to Islamic solidarity in abstract terms, the shah introduced yet another novelty by devoting mass prayers from his House and various circles in Iran to the Ottomans so that the latter succeed in their holy endeavor. The Safavid acknowledgment of Ottoman superiority in hierarchy and in accomplishment as expressed through the Islamic concepts of caliphate and jihad increased in precision. On the other hand, the House of Șafi also re-internationalized its longstanding claim to descend from Prophet Muhammad's cousin and husband of his daughter Fāțima, 'Alī b. Abu Țālib.

In 1103/1692, Ahmed II sent his reply, whereby the Sublime Porte acknowledged the House of Șafĩ as "the [Muhammedan] Mușțafavid dynasty." Then, by citing the verse "fulfill the oath, indeed there is responsibility in oath [Q 17:34]"

\footnotetext{
11 Nāme-i hümāyūn v, ent.63.

12 See Kennedy, The caliphate 281-289, 341-346.
} 
and Muhammad's saying "the goodness of oath [arises] from faith," it also declared that adherence to the current Ottoman-Safavid treaty was a religious obligation. Further emphasis on the same point was made with the hadith "the faithful are like [parts of] a structure, each upholds the other," and the verse "hold firmly to the rope of God all together, and do not separate. And remember the favor of God upon you, when you were enemies, He reconciled your hearts, and you became, by His favor, brothers [Q 3:103]." Besides, the reason for the delay in the issuance of the reply was stated to be Ahmed II's preoccupation with the endeavor against the infidels. In this regard, he wrote to the shah: "it is [Our] expectation from his royal highness that he have his share of the [heavenly] remuneration for ghazä; and that as required by the [revelation] cooperate in righteousness and piety [Q 5:2], the elders and worshippers and the righteous and ascetics in those [Iranian] abodes of straightforwardfoundation, who strive in the way of [God], succor with prayers the ghäzis who are the patrons of the noble sharia and guardians of the luminous Muslim community (millet-i Haniffye-yi beyża $)$, and the celestially-victorious army of Islam."13

The exchanges between 1099/1688 and 1102/1691 offer the first evidence that direct citations from the Quran could serve to support not only a party's unilateral assertion but also a mutually agreed status quo. Now, the 1103/1692 imperial epistle, in a new step, represented the upholding of the Ottoman-Safavid peace as a religious obligation with direct, express, and multiple references to the word of God and the Prophet. Using a Quranic verse, it even references the concept of brotherhood in religion, going beyond the principle of theoretical solidarity between coreligionists. Such buttressing of the Ottoman-Safavid contractual relationship through the divine word was the second and thus far the firmest step taken toward the Ottoman dynasty's acknowledgment that the Safavid state was a legitimate and lawful Islamic monarchy, and that peace with it had now become everlasting.

It is no coincidence that, in response to Shah Süleymān's previous statement, Sultan Ahmed II called on him again to have the Iranians pray for their Ottoman coreligionists waging holy war, as a result of which the Safavids would receive a share of the heavenly benefit from the Ottoman-led struggle. The introduction of this concept of partnership in divine remuneration for good deeds was no less a revolution in the relations between the foremost Shi'ite and Sunni polities of the age than citing the Quran in order to qualify bilateral relations as brotherly. Last but not least, although the House of Șafì's aspiration toward 
the lesser caliphate was left hanging in the air, the nominal recognition of its claim to descend from the Prophetic House (ahlal-bayt) should be seen as the consequence of the accord reached in greater matters. Indeed, as Vefa Erginbaş's paper in this volume demonstrates, the veneration of the ahl al-bayt was an important aspect of Ottoman piety and constituted a major arena of symbolic and discursive competition between the Ottomans and Safavids, in light of which this recognition of the Safavid claims was a major concession.

In his 1107/1696 letter, Shah Husayn fully honored the newly established Islamic status quo between the two states. By qualifying Sultan Muștafā II as being "the Muhammedan (Muhammedī-mezheb) keeper of the frontier of Islam and the Faith, heir to the service of the Two Illustrious Sanctuaries, protector of Islam, and keeper of the sharia," the shah emphasized the sultan's Muslimness much more than even the Sublime Porte itself did, as an extension of the Safavids' internalization of the principle of Ottoman supremacy on all platforms. In the same vein, Shah Husayn also called Muștafā II the "world-bestower via whom the religion triumphed, the Bountiful Monarch of the manifest verse, and Greater Caliph."14

Next year, Muștafā II sent his reply. By referring to the shah's ancestry of "immaculateness (țahāret) [and] seyyidhood," the Sublime Porte affirmed its recognition of the House of Șafi's claim to prophetic lineage. The text, adorned with many Quranic verses, features a lengthy narration of the ongoing war against the Christian Holy League, "the enemies of religion," and then asserts the position of the House of 'Osmān as the hereditary and rightful flag-bearer of Islam in the struggle against unbelief due to the dynasty's "sublime caliphate" girded by God, which also came with the responsibilities of safeguarding the Islamic community. For this reason, stressed Muștafā II, his "caliphal Highness" himself engaged in jihad, following the example of his "jihad-accustomed stock."

Muștafā II also referred to himself and the shah as "affectionate [toward each other] through God." Then, he repeated his predecessor's statement regarding the obligatory nature of the Ottoman-Safavid contractual relationship by citing the verse "and fulfill the oath [to God] when you pledge it [Q 16:91]"-in evocation of Shah Șafi's deed of oath given to Murād IV during the ratification of the peace of Zuhab in 1049/1639 — and added: "it is considered impossible for contracts concluded at the behest of [the mentioned verse] to be broken." Along the same lines, Musțafã II described the nature of bilateral relations with reference to the verse "the faithful are but brothers [Q 49:10]." As the padishah 
concluded his letter, he expressed his "hope that his Highness [the shah], would as a declaration of faith, also become a co-rider [in the sultanic troops' holy endeavor] with [an] army of prayers." 15

In his own reply to the shah, the grand vizier additionally underscored the sultan's dignity through titles coined from Islamic concepts, such as the "aider of Islam and the Muslims, collector of the signs of religiosity (cāmi'-i āyāt-ı dīn$d \bar{a} r \bar{\imath})$, upholder of Muhammed's sharia, refuge of Islam." As had happened in the previous round of correspondence, the grand vizier announced: "as there is the intention of jihad this year, it is demanded that You make Your [God]answered prayer for the army striving in the path of God's oneness, and not spare Your diligence towards partaking in the divine remuneration of ghaz $\bar{a}$ via gathering prayers from the ulama, the elders, the righteous, and the pious who are at ease in Your extensive domains."16

By this correspondence, beyond the consolidation of the previously introduced concepts, the Sublime Porte for the first time defined with Quranic verses not only the formation of a contractual relationship with the Safavids but also its due continuation, thus implying the obligatory nature of adhering to it and referring to the perpetuation of the peace between these Shi'ite and Sunni monarchies.

In his 1109/1698 epistle, Shah Husayn called the Ottoman pädishāh the "refuge of religion, victory-bringer to Islam and the Muslims, suppresser of the infidels, servant of the Two Illustrious Sanctuaries, redoubled shadow (zill- $\iota$ $z a l \bar{\imath} l)$ of [God] the Merciful." Then, the shah once again designated the Ottoman war against the Christian Holy League as "ghazā against the infidels," and the subjects of both Iran and the Ottoman Empire collectively as the "community of Islam."17

In his reply, Muștafā II did not refer to the Islamic qualifications of his Safavid correspondent, as in the previous imperial missives, but he still cited the verse "you became, by His favor, brothers [Q 3:103]."18 In his parallel letter to the shah, Köprülü Amcazāde Hüseyin Pasha greeted his addressee as the "light of the garden of [Muhammad] Muștafāa, the befitting one to ['Alī] the gem of Najaf." Yet, he referred to the "caliphal [Ottoman] hearth" and to Mușțafā II as the "servant of the Two Illustrious Sanctuaries, aider of Islam and the Muslims, victory-bringer of the jihad-strivers, refuge of Islam, greater shadow of God." Regarding the Safavids' active cooperation in restituting Basra to the Ottomans,

\footnotetext{
15 Nāme-i hümāyūn v, ent.10o.

16 Nāme-i hümāyūn v, ent.112.

17 Nāme-i hümāyūn v, ent.12o.

18 Nāme-i hümāyūn v, ent.121.
} 
after it had been under rebel rule for several years, the grand vizier wrote that this act by the shah was meant to aid the Ottoman struggle against the Holy League-i.e., an "aid-of-victory to religion."19 In his separate letter to the Iranian chief vizier, Köprülü Amcazāde Hüseyin Pasha additionally called the sultan "God's shadow in both worlds" as opposed to which he styled the shah as the "shadow of the clemency of the God" (sāye-i refet-i Yezdān). ${ }^{20}$

In 1111/1699, the Safavid court sent its counter replies. In the royal epistle to Mușțafā II, the sultan was again hailed for his "piety." The moment of the imperial epistle's arrival was depicted in a narration richly embellished with Quranic verses. The goal of the Ottoman army in the ongoing struggle against the Christian Holy League was underscored to be the "exaltation of the word of God, notification of the express religion, [and] endeavor against the infidels." The "expediencies of the manifest religion (din-i mübin) and the order of the affairs of the Muslims" were highlighted to be the desire of both parties. ${ }^{21}$ In a separate royal epistle to the grand vizier, the shah distinguished the padishah as the "helper of Islam, greater shadow of [God] the Merciful."22 The Iranian chief vizier's reply to Köprülü Amcazāde Hüseyin Pasha qualified the grand vizier as the "arm of the manifest caliphate (hiläfetül-müstebin), [and] mast of the [Muslim] nation and religion," while revering the sultan as the "greater shadow of God [and] refuge of Islam."23 The grand vizier's follow-up letter to the chief vizier in $1112 / 1700$ conformed to the by-now established precedents and titled the padishah, among other things, as "God's shadow in both worlds" and the shah as the "shadow of the clemency of the Deity." 24

The 1109-1112/1698-1700 correspondence between Adrianople, where the imperial court then resided, and Isfahan constituted the zenith of the fraternization between the Shiite Safavids claiming to rule in the absence of the Twelfth Imam and the Sunni Ottomans claiming to possess God's vicegerency on earth. In line with the recent revival of the distinctions in the concept of caliphate, the Sublime Porte styled itself with the by-now established references to the greater caliphate. However, it also made a novel allusion to the Safavids' lesser caliphate through a reference to the shah's being the shadow not of God himself but of an attribute of God (i.e., his clemency; refet). Other than rhetorical diversification, this round of correspondence featured a repeated,

\footnotetext{
19 Nāme-i hümāyūn v, ent.125.

$20 \quad$ Nāme-i hümāyūn v, ent.126.

21 Nāme-i hümāyūn v, ent.155.

22 Nāme-i hümāyūn v, ent.157.

23 Nāme-i hümāyūn v, ent.156.

24 Nāme-i hümāyūn v, ent.18o.
} 
consolidated, and full adherence to the rest of the established concepts representing the recent Islamic rapprochement. Never had these polities championing Shi'ism on the one hand and Sunnism on the other interacted more harmoniously under the banner of Islam.

This leniency of the Ottomans, however, came to an end once their war against the four great powers and their lesser allies was concluded by the Treaty of Karlowitz in 1111/1699. The Safavid chief vizier's letter to the Ottoman grand vizier in 1114/1702 referred to the latter as the "reliance of the supreme caliphate," and to the sultan as the "refuge of Islam, shadow of God," while it qualified the shah's dignity as the "[lesser] caliphal throne." ${ }^{25}$ The grand vizier's reply fell visibly short of satisfying Safavid expectations, for it contained none of the explicit references to the Islamic attributes of the Safavids that the Sublime Porte had formulated and used in their correspondence over the previous decade. Yet, the grand vizier did not fail to describe the sultan with supreme Islamic titles such as the "patron of the religion, aider of Islam, [celestially]victorious with the help of [God] the best of the victory-aiders, shadow of God, [and] refuge of Islam." 26

As it happened, in the interval between 1099/1688 and 1103/1692, the initiative to alter the Islamic status quo between the parties came from the Ottoman state. In response to the Iranian chief vizier's letter that was antagonizing in content but compliant in form, the grand vizier retaliated with double the hostility received and stripped the Safavid side of nearly all of their recently recognized Islamic qualifications. The shah no longer enjoyed a territorial caliphal dignity, prophetic lineage, coreligionist solidarity, or even the full honors of a Muslim sovereign monarch. The undoing of the post-1099/1688 achievements had begun. ${ }^{27}$

The deterioration in relations was yet to reach its peak. In Shah Husayn's epistle of $1117 / 1705$ to Sultan Ahmed III, apart from the traditional reference to the padishah's safeguarding of Mecca and Medina, no title describing his Islamic leadership was inserted. Nevertheless, the text included passages mentioning the Ottomans' "breaking the reinforcement of the infidels," and thus enjoying God's glad tidings "He shall recompense those who do good with the best [award] [Q 53:31]," and "indeed, the Earth belongs to the God, He bequeaths it to whom[ever] He wishes [Q 7:128]." Upon receiving this good news from Ahmed

25 Nāme-i hümāyūn v, ent.218.

26 Nāme-i hümāyūn v, ent.220.

27 For the historical background of this case and all other cases discussed in this essay, see Güngörürler, Diplomacy and political relations; Güngörürler, Fundamentals of OttomanSafavid; Güngörürler, Brotherhood, perpetual peace. 
III, the "sharia-cherisher [and] the pursuer of the road of the Prophet," the shah, addressing the sultan, gave "thanks to God that standard of Islam became elevated due to the stroke of your sharp blade."28

The imperial epistle sent in response opened with an imperious reminder:

[God], by [His] verdict of whom [ever] He wishes and whom [ever] He wills, authorizes an entity to the seat of caliphate for the order of the world, [and by His word] indeed, the Earth belongs to the God, He bequeaths it to whom [ever] He wishes of his servitors [Q 7:128], He bestows [upon this caliph] the monarchy, world-keeping, rulership, and sovereignty, and when His [i.e., God's] pre-eternal providence conjoins his [i.e., this caliph's] height to the zenith of the sky, no one of the connoisseurs of plotting and jealousy can reject. And it is He who has made you vicegerents [i.e. caliphs] on Earth and has raised some of you above the others [Q 6:165].

The epistle's inscriptio included no Islamic honorific other than the reference to Shah Husayn's being the "good successor of the dynasty of ['Alī] the shah of Najaf." In the expositio, one comes across, probably for the first time in decades, the reference to the "coverage of the Sunni community" (şeml-i ehl-i sünnet ve'lcemáat) as one in the set of causes that the Ottoman dynasty championed, alongside the more conventional ones like the "majesty of Islam, symbols of the Muhammedan religion, [and] the sharia." The Sublime Porte concluded its message as follows: "it is [by] the practice of Our great forefathers, that particularly those who are single-hearted with [and] honest towards Islamic rulers have always been [held in] esteem."29

It is noteworthy that in the grand vizier's reply to the shah's chief vizier, the Sublime Porte briefly referred to the shah as "of caliphal station" (hiläfetmertebet), but in return, prayed for the sultan that "God may immortalize his caliphate," and also decorated him with the usual titles emphasizing his patronage of Islam. ${ }^{30}$

Within the scope of the $1117^{-1118 / 1705^{-6}}$ exchange, the Safavids chose to escalate the tensions that had arisen during the previous several years. They alluded to Ottoman dignity in Islamic terms only by referring to the Ottomans' conformity to the divine commandments and distinguished accomplishments in the path of God. Yet, none of these praises concealed the fact that explicit references to the greater caliphate and the set of associated titles denoting Islamic

28 Nāme-i hümāyūn vi, ent.61.

29 Nāme-i hümāyūn vi, ent.66.

30 Rāmī Meḥmed, Münşe’āt 25a-26a. 
primacy were omitted, except for the possibility that an accompanying and bynow nonextant chief vizierial letter might have included them.

This matter claimed the Ottomans' entire attention. In the response epistle, apart from a nominal recognition of prophetic lineage, the Sublime Porte omitted the entire set of references to the House of Șafi's Muslimness, brotherhood in Islam, or the prayer exchanges and partnership arising from coreligionism, save for a single mention of the concept of the lesser caliphate. Moreover, it emphasized the God-designated nature, exclusiveness, and indisputability of the Ottoman universal caliphate posited above all other rulers. While these points were mutually and constructively cited in the previous exchanges, now the Sublime Porte chose to patronizingly evoke them in the face of an unfriendly omission by the Safavids. In order to leave no room for doubt that this assertion was not an untargeted or general declaration but a direct retaliation, the imperial chancery inserted into the composition of the reply the very concepts and Quranic verses found in the royal epistle that initiated the exchange, employing them, however, to the detriment of the original citer. Furthermore, the Sublime Porte briefly touched upon the issue of sectarianism with a mention of Sunni orthodoxy in a diplomatic letter to the Safavids for the first time after at least 67 years. By means of this reference to Sunnism as the correct path of Islam, it insinuated that it indeed regarded the Shi'ites as unorthodox if not heretical, that it could revive the age-old controversy if the Safavid side was not to conform to the status quo by recognizing Ottoman supremacy, and that the nonmention of sectarian discord in the diplomatic correspondence between the parties for almost seven decades was for the sake of political expediency, which the Safavids better observe for their own good. Consequently, the reminder about how to enjoy esteem in Islamdom led by the Ottomans carried an admonishing rather than an encouraging tone.

Correspondence between monarchs resumed after a ten-year break. In its manner of imposing the Ottoman universal caliphate, the epistle of the conquest of the Peloponnese in 1128/1716 partially resembled the one from 1118/ 1706: "The Creator, by His pre-eternal grace and [His revelation] We made you vicar [caliph] on Earth [Q 38:26], certified Our caliphal Highness to uphold the frontiers of Islam hereditarily and rightfully. And Our caliphal Highness, not regarding the might of monarchy as a tool for self-advancement or boonenjoyment, devoted time to secure the borders [of Islam] with ghaza and jihad, and the localities of infidelity became illuminated with symbols of Islam."

This was followed by a lengthy narration of the campaigns of the OttomanVenetian War, interspersed with multiple Quranic verses on jihad and references to the Ottomans' single-handedly waging it in the name of God as the army of Islam against the unbelievers. Eventually, the sultan declared that the 
motive for the sending out of the epistles of conquest, among the receivers of which was the shah of Iran, was that "the proclamation of this sublime [victory] procession [would] cause the hearts of the people of Islam to relax." ${ }^{31}$

The parallel letter sent to Shah Husayn by the grand vizier, after a prologue on jihad, mentioned some of the Islamic titles of the sultan as "enhancer of the Muhammedan sharia, infidel-melter, champion of ghazā and jihad, mirror of the religion, honor of the Muslim community, essence of the Ottoman caliphal dynasty, refuge of Islam, greater shadow of God, immortalized shall his caliphate be until the day of resurrection."

In the rest of the narrative, the grand vizier associated the Quranic verses on jihad and Muhammad's sayings on God-given victory with the person of his lord Aḥmed III. Dāmād (Şehīd) 'Alī Pasha and concluded: "it is always expected from Your royal efforts that Your prayers for [celestial-] victory and confirmation of the [Ottoman] army, and [thus] [Your] obtainment of a share from the shares of [our] ghazā, be vouchsafed." ${ }^{32}$

Shah Husayn's reply to Ahmed III stated that by conquering territory from the Republic of Venice, the sultan, just as his forefathers had traditionally done, merited God's promise that the ghäzis would prevail against enemy armies and rejoice in heaven as remuneration. After honoring his addressee as the "patron of Islam [and] the Muslims," the shah renarrated the stages of the war as he had read them from the Ottoman correspondence, but with even more Islamic references than featured in the original, inter alia extolling his addressee for converting churches to mosques and rings of bells to prayer calls. Husayn claimed that the Safavids had contributed to the Ottomans' celestial-victory; for he, with the "most sublime effort, [had] truly asked for succor" that God materialize his promise- "indeed, We have given you a clear conquest [Q 48:1]" —and help the Ottomans triumph. The shah added that, motivated by orators from the pulpits of the mosques, congregations of all social backgrounds in Iran prayed and would keep praying in thanksgiving for this boon by God as well as for the perpetuation and continuation of such conquests through ages. ${ }^{33}$

In this case of an epistle of conquest narrating a major victory portrayed as jihad, the Sublime Porte again chose to assert the sultan's hereditary, rightful, God-given, supreme caliphate and universal leadership of Islam, maybe without directing the assertion negatively toward the person of the shah, but still in a correspondence addressed to him. Yet, the descriptions used and the discourse constructed therefore, while not resembling the constructive tone

31 Nāme-i hümāyūn vi, ent.221.

32 Nāme-i hümāyūn vi, ent.222.

33 Nāme-i hümāyūn vi, ent.246. 
dominant during the period between 1099/1688 and 1112/1700, was not as overbearing as in 1118/1706 either, indicating a relative relaxation of tensions. The reintroduction of the concepts of prayer exchange and partnership in divine remuneration is even more noteworthy and tangible evidence of this, with the exception that there was no mention or even implication of the lesser caliphate for the House of Safi. Nevertheless, the long-ignored and sensitive issue of sectarian discord, which had been brought up once in 1118/1706 in the manner of an implicit warning in the midst of mounting tensions, was again shelved.

In his reply, the shah did not fail to honor the Ottomans' Islamic dignity, as he underscored that the House of 'Osmān had been and still was the manifestation of God's promise for those who strive in His way. Plus, though not directly citing the caliphate itself, the Safavids nonetheless restored their recognition of the Ottomans' supremacy by mentioning the padishah's patronage of Islam and the Muslims - a description, if not identification, of the caliphate. They also returned the Ottoman gesture of good will by stating that the Iranians did and would pray to God for Ottoman victory, which they indeed regarded as the triumph of Islam. Thus, the 1128/1716 correspondence halted the loss of the common ground between the Shi'ite Safavids and Sunni Ottomans. There was even a relative restoration of the previous achievements on the diplomatic platform, but certainly not up to the level of the last decade of the seventeenth century.

The final round of diplomatic correspondence between the two parties took place between $1132 / 1720$ and $1135 / 1722$. Briefly stated, the Sublime Porte once again reasserted the God-given nature, exclusiveness, and universality of the Ottoman monarchy and caliphate through Quranic references. On the other hand, it continued to recognize the prophetic lineage of the House of Şafi and its brotherhood in religion with the House of 'Osmann. In return, the Safavids renewed their recognition of the Ottomans' patronage of Islam and supreme caliphate. $^{34}$

\section{$2 \quad$ Evaluation}

One of the most important concepts that come to the fore in the context of the post-Zuhab Ottoman-Safavid correspondence is the caliphate. As a standard practice during the examined period, the Safavid court acknowledged the Ottomans' greater caliphal dignity by inserting the relevant descriptors into the 
sultans' inscriptio, such as "God's shadow," "refuge of Islam/religion," "servant of the Two Illustrious Sanctuaries," and "victory-bringer/patron of Islam." These were reinforced by a strong emphasis on the Ottomans' successfully leading the armies of Islam against the unbelievers. Even without the explicit mention of "caliphate," the references to leading the jihad, patronizing Islam as well as the Muslim community, and organizing the pilgrimage (hajj) constitute firm evidence of this acknowledgment, for these concepts were directly associated with caliphal prerogatives. In times of extraordinary rapprochement, the Safavid state took this acknowledgment to a higher level by directly referring to the Ottoman "greater caliphate" in phrases such as "[extended] shadow of God," and complementary honorifics such as "establisher of the foundation of Islam" and "sign of God." The correspondence in the examined period thus shows that the Safavids made abundant references, both direct and indirect, to the Ottomans' caliphal supremacy, leaving no room for ambiguity.

For its own part, in diplomatic correspondence with the Safavids, the Sublime Porte consistently made claims to the [greater] caliphate through sultanic titulature. However, it did not try to act upon the universal, extraterritorial dimension of this office (i.e., it did not attempt to revive the practice of issuing caliphal investiture diplomas for monarchs and princes whose territory of rule lay outside the Ottoman Empire). The fact that the Ottoman sultans did not adopt the title "commander of the faithful" (emirül-müminin), one of the attributes of the early universal caliphate, must be because the validity of their caliphal dignity in the eyes of other sovereign states was only a matter of precedence and supremacy in rank, not of subordination in a chain of command. Yet, the Sublime Porte did expect, and mostly receive, nominal recognition of the theoretical universality of the Ottoman sultan's divine mandate, because the caliphal dignity had blended into the imperial rank, where it lived on as a set of titles. Rare instances of the Safavids' failure to honor in writing this (greater) caliphal dimension of the Ottomans' supreme monarchy resulted in the Sublime Porte's effectively imposing the claim to the God-designated, universal, and exclusive nature of the sultan's hereditary caliphate in the next outgoing correspondence. ${ }^{35}$

As seen above, when the nature of the Ottoman-Safavid contractual relationship became Islamicized, its observance was formalized through references to the Quran. This was the result of the Ottoman acknowledgment of the the concept of caliphate in Mughal-Ottoman diplomacy. Also see Moudden, The idea of the caliphate 103-112. 
legitimacy of Safavid rule in Iran, and in turn gave it a further boost. The Sublime Porte's recognition of the Safavid shahs as territorial caliphs (i.e., as fully independent, legitimate, Muslim, and sovereign monarchs who were inferior to the greater caliph only in terms of titulature and hierarchical precedence) was the ultimate manifestation of this novel Islamic legitimacy in Ottoman-Safavid relations. However, this diplomatic recognition did not entail a doctrinal reconciliation between the Shi'ite and Sunni theologians; it was constructed on a separate discursive plane.

Beyond the caliphate, the two most prominent aspects of this diplomatic discourse that enabled peace to last for 84 years were, first, that the Sunni Ottomans neither declared the Shi'ite Safavids as "infidels" nor hinted at it, and second, that the Safavids unreservedly recognized the Ottomans' supreme position as greater caliphs at the top of the hierarchy of rulers in Islamdom. This phenomenon must be the outcome of two separate but concurrent developments. On the one hand, it seems that the Ottomans came to recognize the eventual Shi'itization of the originally Kızılbaş Safavid polity. In the eyes of the Sunni establishment of the age, Kizllbaşism was a heresy that violated the founding principles of Islam and thus rendered its adherents non-Muslim, while Shi'ism was a deviation from the orthodox belief yet still within the circle of Islam. ${ }^{36}$ On the other hand, an uninterrupted peace of 84 years enabled the parties, but again primarily the Ottomans, to maintain this status quo without resorting to a renewed fatwa on unbelief or polemical treatise. It is likely that the Ottoman recognition of the Safavids' Muslimness was the product of a belated Ottoman realization of the post-936/1530 gradual Shi itization within the Safavid establishment, while the continuity of this recognition in the diplomatic discourse for almost nine decades was made possible by the uninterrupted peace. Enjoying Islamic legitimacy in the eyes of the Ottomans mattered much to the Safavids. The shah's court made the due effort to convince the Ottoman State of the Safavids' orthodox Shi'ite, if not Sunni, Muslimness, and thus, by implication, their disassociation from the Kızllbaş faith.

36 For the Kızılbaş-Shi'ite distinction, see Tekindağ, Yeni kaynak 54-55; Düzdağ, Ebussu'ûd Efendinin fetvaları 135-137; Eberhard, Osmanische Polemik 71-75, 85-88, 99, 101, 117, 130; Fığlalı, Eş-Şirvani ve risalesi 26o-265; Ocak, Türk sufiliğine bakışlar 237-238, 245-249; Emecen, Zamânın İskenderi 9o; Bilge, Yavuz Selimve Şah İsmail 311; Arjomand, The shadow of God 81, 110, 179; Savaş, XVI. asırda Alevilik 166, 213; Abisaab, Converting Persia 8-12, 24; Pārsādūst, Shāh Tahmāsb 6o7-613, 809-816, 850-853; Posch, Osmanisch-safavidische Beziehungen 172-176. I discussed these and other sources on the mentioned topic in my paper "Die Frage der Abgrenzung zwischen offiziellen Sekten: das Osmanische Reich und safawidisches Persien in der Frühneuzeit" presented in Forschungskolloquium Lehrstuhl Aserbaidschans at Humboldt-Universität zu Berlin in 2016. 
On the other hand, one does not need to look for the traces of such rethinking on the part of Safavid Iran, for it, despite the sectarian discord, had recognized from almost the very beginning not only the Ottomans' Muslimness but also their leadership in and of Islamdom. ${ }^{37}$ This simply continued throughout the studied period.

Any variation on the religious platform took place within the parameters of this framework. Unless the political situation necessitated it, the Sublime Porte contented itself with referring only rarely and in passing to a Safavid monarch in a manner reserved for Muslim addressees. Only when the international conjuncture urged closer coordination with the Safavids did the Ottomans, of their own accord, promote the common ground under the banner of Islam. In bilateral relations, the concept of brotherhood in religion, the exchange of prayers, partnership in divine remuneration for good deeds, and recognition of the House of Safi's claim to prophetic lineage and the lesser caliphate that emerged after 1097/1686 were part of a greater diplomatic initiative of the Sublime Porte to secure Safavid neutrality and cooperation in the empire's ongoing war against the alliance of the German states, Poland, Russia, and Venice, which necessitated the full mobilization of the empire's deployable power away from the Iranian frontier. Likewise, the introduction of these novel Islamic concepts in Ottoman-Safavid diplomacy went hand in hand with diplomatic concessions that the House of 'Osmān made to the House of Șafì. Later, as this practical urgency disappeared, so did the Sublime Porte's incentives to uphold these recently granted, Islamically inclusive honors for the Safavids. From 1114/1702 onward, the Ottomans at times cut down on their formulations referring to these concepts, and at times completely refrained from mentioning them (i.e., withheld the recognition). Yet, it is remarkable that these achievements on a common Islamic platform resurfaced when the circumstances of the time allowed, such as during the last decade of relations.

Despite their active participation in imperial consultative assemblies and some policy formulation initiatives in the later eleventh/seventeenth and twelfth/eighteenth centuries, the Sunni ulama of the Ottoman Empire do not seem to have played any role in the Sublime Porte's briefly declaring the Safavid shahs as brothers in religion and lesser caliphs, calling for the Safavids to pray for Ottoman victory, offering them in return partnership in the remuneration accruing from the Ottomans' deeds in the way of championing Islam, and honoring the House of Șafi's claim to descend from 'Alī. This agreement was apparently the work of dignitaries and bureaucrats, not the ulama. The mentioned 
development, however, is not linked to the bureaucratization and secularization or Islamicization of the Ottoman state apparatus, and should accordingly be understood as a case-specific phenomenon that arose due to the interstate conjuncture. In short, the ulama's being kept out of the post-1049/1639 Safavid relations was the result of the acknowledgment, both in the empire and in Iran, that only the prioritization of the Realpolitik over doctrinal matters could bring about a mutually beneficial status quo. As a matter of fact, under altered circumstances after 1135/1722, the ulama would be re-allowed to assume a role in Iranian-Ottoman diplomacy; however, exactly as in the previous period, the peace would be reestablished on practical foundations and without reaching an agreement on the religious matters of contention.

The Safavids were not in a position to reply in kind to these Ottoman concessions because they had been honoring these and similar qualities of the Ottomans from the outset. Yet, in order to duly respond to the Sublime Porte's friendly step taken toward them, the Safavids placed extraordinary emphasis on the House of 'Oșmān's exclusive and God-given caliphate, Islamic primacy, universal patronage of the Muslims, and international leadership in championing the religion. It is noteworthy that the phrases with which the Safavids chose to elaborate on these attributes of the Ottomans mostly matched and occasionally even surpassed in extolment those formulated by the Sublime Porte itself.

As the religion of Islam was now construed as the common ground, the issue of the sectarian discord between Shi' ism and Sunnism barely surfaced in interstate diplomacy. Except in one isolated case that occurred when relations were at their nadir, the parties did not refer to their sectarian/denominational identity, let alone bring up their conflicting views on orthodoxy. Sectarian differences had been used for justifying hostilities in the pre-Zuhab period, but in relations based on peaceful coexistence after 1639, there was no place for such references. Had the ulama been involved, the almost-one-millennium-old doctrinal positions rejecting each other would have inevitably come up and informed the drafting of the diplomatic correspondence, which would have been contrary to the desired goals. In light of these goals, the governments, opting to benefit from Islam as a unifying force in the service of Realpolitik rather than as an inexhaustible repository from which to extract religious justifications for conflict, stayed clear from a polemic on orthodoxy and heterodoxy.

The fall of the Safavid state in 1135/1722 upset overnight the status quo of 84 years, and thus the Shi'ite-Sunni political conciliation. In the Ottomans' engagements with the Hōtakī Afghans, the Safavid claimants, and ultimately the polity of Nādir Afshār until the mid-twelfth/eighteenth century, religious 
and sectarian matters would assume a place at the top of the agenda, in form as well as in content. ${ }^{38}$ Hence, the intersectarian harmony brought about by political will would be undone, again by the altered political situation.

\section{Acknowledgments}

Research for this essay was supported by the European Research Council (ERC) Consolidator Grant under the European Union's Horizon 2020 research and innovation programme (grant agreement No 648498).

\section{Bibliography}

\section{Primary Sources}

Nāme-i hümāyūn defteri v-VI, T.C. Cumhurbaşkanlığı Devlet Arşivleri (formerly, Başbakanlık Osmanlı Arşivi).

Cantemir [Kantemiroğlu] Demetrius, The history of the growth and decay of the Othman empire, London 1734.

Cevrī İbrāhīm Çelebi and Șarı 'Abdullāh Efendi, Düstūrü'l-inşā, Süleymaniye Kütüphanesi, Ms Nuruosmaniye 4304.

Düzdağ, M.E. (ed.), Şeyhülislam Ebussu'ûd Efendinin fetvalarına göre Kanuni devrinde Osmanlı hayatı, Istanbul 2012.

Evoğlu Ebulkasım Haydar Beyg, Mecma ü̈l-inşâ, British Library, Ms. Add. 7668.

Navāī, A. (ed.), Asnād u mukātabāt-i siyāsī-yi İrān az săl-i 1038 tā 1105, Tehran sh.136o.

Navāī, A. (ed.), Asnād u mukātabāt-i sìyāsi-yi İrān az sāl-i 1105 tā 1135, Tehran sh.1363.

Qazvīnī-Isfahānī Muhammad Yūsuf Vālih, Khuld-i barīn [İrān dar zamān-i Shāh Safìvu Shāh Abbās-ı Duvum], ed. M.R. Nasīīi, Tehran 2003.

Rāmī Meḥmed, Münş̧e’āt, Österreichische Nationalbibliothek, H.o. 179.

\section{Secondary Sources}

Abisaab, R.J., Converting Persia: Religion and power in the Safavid empire, London 2004. Akbulut, M.Y., The scramble for Iran: Ottoman military and diplomatic engagements during the Afghan occupation of Iran, 1722-1729, MA thesis, Boğaziçi University 2015.

38 See Aktepe, 1720-1724 Osmanlı-Íran münâsebetleri; Külbilge, 18. Yüzyllın; Koca Râgıp Paşa, Tahkikve tevfik; Tucker, The peace negotiations; Güngörürler, Diplomacy and political relations; Akbulut, The scramble for Iran. 
Aktepe, M., Osmanlı-Iran münâsebetleri ve silâhşör Kemânî Mustafa Ağa'nın Revân Fetih-nâmesi, Istanbul 1970.

Arjomand, S.A., The shadow of God and the Hidden Imam: Religion, political order, and societal change in Shi'ite Iran, Chicago 1984.

Baer, M.D., The great fire of 166o and the Islamization of Christian and Jewish space in Istanbul, in IJMES 36 (2004), 159-181.

Bilge, R., 1514: Yavuz Selim ve Şah İsmail: Türkler, Türkmenler ve Farslar, Istanbul 2010.

Casale, G., The Ottoman age of exploration, New York 2010.

Çiftçi H., Osmanlı-Safevi ilişkilerinin diplomatik dili, PhD diss., Çankırı Karatekin Üniversitesi 2015 .

Diyanet, A.E., İlk Osmanlı-Iran anlaşması (1555 Amasya musalahası), Istanbul 1971.

Dressler, M., Inventing orthodoxy: Competing claims for authority and legitimacy in the Ottoman-Safavid conflict, in H. Karateke and M. Reinkowski (eds.), Legitimizing the order: The Ottoman rhetoric of state power, Leiden, 2005.

Eberhard, E., Osmanische Polemik gegen die Safawiden im 16. Jahrhundert nach arabischen Handschriften, Freiburg am Breisgau 1970.

Emecen, F., Zamânın İskenderi, şarkın fâtihi: Yavuz Sultan Selim, Istanbul 2010.

Farooqi, N.R., Mughal-Ottoman relations: A study of political and diplomatic relations between Mughal India and the Ottoman Empire, $155^{6-1748, ~ P h D ~ d i s s ., ~ U n i v e r s i t y ~ o f ~}$ Wisconsin-Madison 1986.

Fığlalı, E.R., İbn Sadru'd-din eş-Şirvani ve itikadî mezhepler hakkındaki Türkçe risalesi, in Ankara Üniversitesi ilahiyat fakültesi dergisi 24 (1981), 249-276.

Güngörürler, S., Diplomacy and political relations between the Ottoman Empire and Safavid Iran, 1639-1722, PhD diss., Georgetown University 2016.

Güngörürler, S., Fundamentals of Ottoman-Safavid peacetime relations, 1639-1722, in Turkish historical review 9 (2018), 151-197.

Güngörürler, S., Brotherhood, perpetual peace, and alliance in Ottoman-Safavid relations, 1688-1698: A diplomatic revolution in the Middle East, in Turcica 50 (2019), $145^{-207 .}$

İnalcık, H., Osmanlı sultanlarının halifeliği sorunu, in H. İnalcık, Devlet-i Aliyye i, Istanbul 2009 .

Kennedy, H., The caliphate, London 2016.

Krüger, H., Fatwa und Siyar, zur internationalrechtlichen Gutachtenpraxis der osmanischen Şeyh ül-Islâm vom 17. bis 19. Jahrhundert unter besonderer Berücksichtigung des "Behcet ül-Fetâvâ," Wiesbaden 1978.

Külbilge, İ., 18. yüzyılın ilk yarısında Osmanlı-İran siyasi ilişkileri (1703-1747), PhD diss., Ege Üniversitesi, 2010.

Küpeli, Ö., Osmanlı-Safevi münasebetleri (1612-1639), Istanbul 2014.

Kütükoğlu, B., Osmanlı-Iran siyasi münasebetleri (1578-1612), Istanbul 1993.

El Moudden, A., The idea of the caliphate between the Moroccans and Ottomans: Polit- 
ical and symbolic stakes in the 16th and the 17th century-Maghrib, in SI 82 (1995), 103-112.

Murphey R., Süleyman's eastern policy, in H. İnalcık and C. Kafadar (eds.), Süleyman the second and his time, Istanbul 1993.

Ocak, A.Y., Türk sufliğine bakışlar, Istanbul 1996, repr. 2014.

Özcan, A., Hilâfet (Osmanlı dönemi), in TDVIA 17 (1988), 546-553.

Özen, Ş., Osmanlı döneminde fetva literatürü, in Türkiye araştırmaları literatür dergisi 3 (2005), 249-378.

Pārsādūst, M., Shāh Tahmāsb-i Avval, Tehran 1381.

Posch, W., Osmanisch-safavidische Beziehungen (1545-1550): Der Fall Alkas Mirza, Wien 2013.

Savaş, S., XVI. asırda Anadolu'da Alevilik, Ankara 2013.

Sohrweide H., Der Sieg der Safawiden in Persien und seine Rückwirkungen auf die Schiiten Anatoliens im 16. Jahrhundert, in Der Islam 41 (1965), 95-223.

Tekindă̆, Ş., Yeni kaynak ve vesikaların ışığı altında Yavuz Sultan Selim'in İran seferi, in İstanbul Üniversitesi edebiyat fakültesi tarih dergisi 17/22 (1968), 49-78.

Tucker, E., The peace negotiations of 1736: A conceptual turning point in OttomanIranian relations, in Turkish studies association bulletin 20 (1996), 16-37.

White, J., Fetva diplomacy: The Ottoman şeyhülislam as trans-imperial intermediary, in Journal of early modern history 19 (2015), 199-221. 